\title{
Community-based interventions for building social inclusion of refugees and asylum seekers in Australia: A systematic review
}

\author{
Di Mahoney \\ Griffith University \\ Samantha Siyambalapitiya \\ Griffith University
}

\begin{abstract}
As refugee and asylum seeker numbers increase in Australia, their effective integration into society is facilitated by inclusion in social, economic and community life. This systematic review of the literature explored community-based programs that contribute to inclusion and social participation of refugees and asylum seekers in Australia. Four scholarly databases were searched for articles published between 2007 and 2017 resulting in five articles which met inclusion criteria. Although the studies identified were of variable quality, the findings suggest a number of factors that facilitate program effectiveness. These included where: (a) English language and communications skills were considered; (b) programs built on refugees' own skills and experience prior to resettlement; (c) volunteers and mentors were involved; and (d) participants engaged in diverse projects that enabled new connections. The review highlights the paucity of well-researched interventions that build social inclusion of refugees and asylum seekers in Australia. Emerging evidence suggests that communitybased programs can positively increase social inclusion and connectedness amongst refugees and asylum seekers. Additional well-designed programs and evaluation of such programs are needed to better understand and identify effective interventions targeting social inclusion of refugees and asylum seekers.
\end{abstract}

Keywords: asylum seekers, refugees, inclusion, social participation, recreation, community programs

With unprecedented and increasing populations of refugees worldwide seeking safety in other countries, there is considerable media attention on, and public discourse about, their successful integration into social, economic and community life in host countries (Benson, 2017; Brown Hamilton, 2016; Cowell, 2015; Paterson, 2015; Postelnicescu 2016; Szabo 2015). Establishing a sense of belonging and social inclusion is recognized as fundamental to successful re-settlement of refugees and asylum seekers in host countries (Ager \& Strang, 2008; Beirens, Hughes, Hek, \& Spicer, 2007; Correa-Velez, Gifford, \& Barnett, 2010; Fozdar \& Hartley, 2013, 2014; Taylor, 2004). Despite the importance of social inclusion programs, and their ability to enable, or contribute to, successful refugee re-settlement, little is known about what makes them effective. This systematic review sought to explore the effectiveness of community-based interventions aimed at strengthening social inclusion of refugees and asylum seekers in Australia.

One of the most widely accepted definitions of a refugee is "any person who owing to a wellfounded fear of being persecuted for reasons of race, religion, nationality, membership of a particular social group or political opinion, is outside the country of his/her nationality and is

Corresponding author: Di Mahoney (di.mahoney@griffithuni.edu.au) 
unable, or owing to such fear, is unwilling to avail himself/herself of the protection of that country" (United Nations High Commissioner for Refugees (UNHCR), 2017). An asylum seeker is "a person who has sought protection as a refugee, but whose claim for refugee status has not yet been assessed" (Refugee Council of Australia, 2016).

According to the UNHCR (2016, para. 2), during 2015, an unprecedented 65.3 million people were forcibly displaced from their homes, including 21.3 million who were identified as refugees. War and civil unrest have contributed to many millions of people being displaced from nations such as Syria, Afghanistan and Somalia (Refugee Council of Australia (RCOA), 2016a). According to the RCOA (2016a), people fleeing these three countries alone account for more than half of the world's refugees and asylum seekers under the UNHCR's mandate, and more than $51 \%$ are children.

Australia has a long history of migration and refugee intake. In the 2016 Australian Census, $49 \%$ of Australians were born overseas, or one or both parents were born overseas (Australian Bureau of Statistics (ABS), 2017). Australia has one of the highest proportions of residents born overseas among all the Organisation for Economic Co-operation and Development (OECD) countries, with Australia being equal second with Switzerland, after Luxembourg (OECD, 2009). Moreover, Australia is considered a successful example of multiculturalism, with surveys conducted by Markus (2016, p2), on behalf the Scanlon Foundation, showing that between 2013 and 2016, 83-86\% of respondents agreed with the statement "multiculturalism has been good for Australia".

Successful refugee settlement and social inclusion are key objectives of the Australian government's humanitarian program (Australian Government, n.d.). Governments at all levels have adopted and funded strategies, policies and programs that aim to build harmonious multicultural communities and support newly arrived refugees and asylum seekers to achieve social and economic integration (Australian Department of Social Security (ADSS), 2016; Logan City Council, 2016). The United Nations Department of Economic and Social Affairs (UNDESA) (2012, para.4) declared that fostering social cohesion is "about striving for greater inclusiveness, more civic participation and creating opportunities for upward mobility".

Social inclusion refers to the degree to which all citizens can "participate on equal footing in the economic, social and political life, including whether people are protected in times of need" (UNDESA, 2012, para. 5). Integration remains significant both as a stated policy goal and as a targeted outcome for projects working with refugees (Ager \& Strang, 2008; ADSS, 2016; Logan City Council, 2016). Integration is broadly recognized as a two-way process that requires refugees to connect and participate in social, economic and community life, and the host community to actively encourage and support their involvement (Fozdar \& Hartley, 2011).

The difficulties associated with refugee settlement are well documented. This includes the need to learn new languages, negotiate differing cultural and societal values, emotional trauma, loss or separation from family and torture or life-threatening events preceding arrival (Ager \& Strang, 2008; Beirens et al., 2007; Correa-Velez et al., 2010; Fozdar \& Hartley, 2013, 2014). The government and community sectors, human services practitioners and many volunteers, play an important role in the delivery of support services aimed at assisting this population to build social connections - such as social bonds, bridges and links. Ager and Strang $(2008, \mathrm{p} 170)$ identified these as critical to achieving social connection and integration into local community life. Programs that aim to build social inclusion are an important aspect of achieving social cohesion and integration of refugees into host societies.

Research into refugee and asylum seeker populations in Australia is a relatively new and developing field, with much of the focus to date on their access to, and experience of, physical and mental health services. Currently little is known about the characteristics, or effectiveness of, community based interventions aimed at building social inclusion. Hence it is necessary, 
to assess the effectiveness of community-based interventions that aim to build social inclusion for this population, in order to ensure that: (a) best practice approaches are identified and shared; (b) public funding is spent on programs that are most effective; and (c) programs achieve the stated policy objectives. This systematic review aimed to identify studies reporting and evaluating community-based programs addressing the social inclusion of refugees and asylum seekers in Australia and to examine the effectiveness of such interventions.

\section{Method}

\section{Search strategy}

A systematic review of studies was undertaken that aimed to conform to relevant items of the Preferred Reporting Items for Systematic Reviews and Meta-analyses (PRISMA) checklist (Moher, Liberati, Tetzlaff, Altman \& the PRISMA group, 2009). This review represents a qualitative systematic review, according to Grant and Booth's (2009) typology of reviews. The databases Pub Med, PsychLIST, CINAHL and Scopus were searched for articles published between 2007 and 2017, focussing on community-based interventions and programs designed to build social inclusion amongst refugees and asylum seekers of all ages in Australia. Additional relevant journals were manually searched because they had a focus in this field, including the Journal of Refugee Studies (Oxford Academic), the Journal of Ethnic and Racial Studies (Taylor and Francis online) and the Australian Journal of Social Inclusion (Griffith University).

\section{Search terms}

Using the PICO method, a set of search terms was identified. The key terms for the database search included (refugee* or asylum seeker*) AND "Australia" AND (intervention or program) AND (inclusion OR social participation OR recreation). These search terms aligned with those from other systematic reviews exploring refugees and asylum seekers, for example, Robjant, Hassan, and Katona (2009), Tyrer and Fazel (2014), Ott and Montgomery (2015).

\section{Study selection}

Database records were screened and selected according to criteria listed below: Inclusionary criteria

1. Community-based interventions that build inclusion and/or social or recreational participation for refugees and asylum seekers of any age

2. Interventions conducted in Australia

3. Studies reporting original research

4. English language publications

5. Studies published between 2007-2017

Exclusionary criteria

1. Individual case studies were excluded as the review was targeting community-based programs which are likely to focus on groups rather than individuals

2. Grey literature

The studies were screened by title and abstract, before reading the full text of the remaining articles to determine final items for inclusion in the review. 


\section{Data extraction and quality assessment}

Data extracted from studies identified for inclusion in the review included location, target population, sample size, type of intervention, research methods used, and a brief description of program outcomes. Given the focus on qualitative research in the studies, a suitable quality assessment tool was identified, namely the critical appraisal methodology outlined by Hannes (2011, p4). Hannes' (2011) system for quality assessment is based on four key concepts: (a) credibility - the degree to which the data presented fits the views of the participants studied; (b) transferability - the degree to which the research findings are transferable to other specific settings; (c) dependability - the degree to which the process of research is logical, traceable and clearly documented, particularly with regard to the methods chosen and the decision made by the researcher; and (d) confirmability - the extent to which the findings are confirmable through the analysis being grounded in the data. A five-point scale (with $5=$ 'very high' and 1 = 'very low') was used to rate studies against Hannes' (2011) four criteria. Total scores based on the four criteria were calculated and an overall assessment was awarded.

\section{Data synthesis and analysis}

Due to significant heterogeneity of the studies, all of which involved qualitative research methods, data was synthesized using thematic analysis. Prominent themes emerging from the studies were identified and the key factors involved in effective community-based interventions are presented below.

\section{Results}

The results of the selection process are summarized in Figure 1. The database search yielded eighty-four studies, with seventy-six remaining after duplicates were removed. Application of the inclusion/exclusion criteria resulted in the removal of sixty-six articles on the basis of title and/or abstract. The remaining ten full-text studies were reviewed and six failed to meet the inclusion criteria because they did not evaluate a community-based program or intervention. Additional manual searches of the bibliographies and relevant journals were conducted and one additional study was identified that met the inclusion criteria. Five studies were therefore selected for inclusion in this review. Table 2 provides a summary of key information from research reports detailing community-based programs for refugees and asylum seekers in Australia.

All studies utilized qualitative research methods, including focus groups and semi-structured interviews. In keeping with qualitative research methodologies, studies had relatively small sample sizes - with the largest identified as 30 and the smallest 12 . The quality of each study was assessed according to Hannes' (2011) scoring system for qualitative research, the results of which are presented in Table 1. 


\section{Figure 1. Flowchart documenting study selection process}




Table 1. Study quality appraisal using Hanne's (2011) quality assessment rating

\begin{tabular}{|c|c|c|c|c|c|c|}
\hline Study & Credibility $^{a}$ & Transferabilitya & Dependabilitya & Confirmability $^{a}$ & $\begin{array}{l}\text { Total } \\
\text { Score }^{b}\end{array}$ & Result \\
\hline $\begin{array}{l}\text { Hallahan } \\
\text { Irizarry (2008) }\end{array}$ & 1 & 2 & 1 & 1 & 4 & $\begin{array}{l}\text { Very } \\
\text { Low }\end{array}$ \\
\hline $\begin{array}{lr}\text { Harris, } & \text { Rowe- } \\
\text { Mississ } & \& \\
\text { Somerset } & (2014) \\
\end{array}$ & 4 & 3 & 4 & 4 & 15 & High \\
\hline $\begin{array}{l}\text { Liamputtong, } \\
\text { Koh, Wollershiem } \\
\text { \& Walker (2016) }\end{array}$ & 4 & 4 & 4 & 4 & 16 & High \\
\hline \multicolumn{7}{|l|}{ Naidoo (2009) } \\
\hline & 2 & 2 & 2 & 3 & 9 & Medium \\
\hline $\begin{array}{l}\text { Riggs, Block, } \\
\text { Mhlanga, Rush \& } \\
\text { Burley (2014) }\end{array}$ & 2 & 2 & 1 & 2 & 7 & Low \\
\hline
\end{tabular}

a. Scores awarded according to a 5-point scale where $1=$ 'very low' and $5=$ 'very high'

b. Total scores represent the following categories: $0-4=$ Very low quality; $5-8=$ Low quality; 9 $-12=$ Medium quality; $13-16=$ High quality; $17-20=$ Very high quality.

The quality of the studies varied greatly with two being high quality, one medium, one low and one very low, as outlined in Table 1. A rating of 'high quality' reflected studies with a more sophisticated and thorough research method, documentation and evaluation process. The studies covered a diverse range of community-based interventions, and no two interventions were alike.

Thematic analysis was used to identify the commonalities present across the studies and any factors that might lead to effective community-based programs, as summarised in Table 2. As a result, the following key elements were identified during the data analysis process and are proposed as features of successful community-based interventions: (a) programs include careful consideration of the English language, communication processes and tools utilized; (b) programs build on, or tap into the cultural knowledge and pre-settlement experiences of refugees and asylum seekers; (c) trained volunteers or mentors are an integral part of the program; and (d) programs offer a diverse range of experiences through which refugees and asylum seekers can create new social connections within their own cultural community or with host community members. 
Table 2. Summary of research reports describing community-based interventions for refugees and asylum seekers in Australia

\begin{tabular}{|c|c|c|c|c|c|c|c|c|}
\hline Study & Location & $\begin{array}{l}\text { Target } \\
\text { population }\end{array}$ & Sample size & Ethnicity & Intervention focus & Study type & Findings & $\begin{array}{l}\text { Quality } \\
\text { rating }\end{array}$ \\
\hline $\begin{array}{l}\text { Hallahan \& } \\
\text { Irizarry (2008) }\end{array}$ & Adelaide & $\begin{array}{l}\text { Refugees and } \\
\text { asylum seekers, } \\
\text { aged } 7 \text { to14 } \\
\text { years }\end{array}$ & Not reported & African & $\begin{array}{l}\text { Recreation } \\
\text { program for school } \\
\text { children to increase } \\
\text { social and } \\
\text { recreation skills }\end{array}$ & $\begin{array}{l}\text { Case report: } \\
\text { Program review } \\
\text { based on five } \\
\text { years of program } \\
\text { development and } \\
\text { delivery. }\end{array}$ & $\begin{array}{l}\text { 1. Recreation programs } \\
\text { can assist childrens' } \\
\text { recovery from trauma } \\
\text { through increased } \\
\text { community involvement in } \\
\text { diverse activities. } \\
\text { 2. More thorough } \\
\text { evaluation is needed for } \\
\text { this program. }\end{array}$ & $\begin{array}{l}\text { Very } \\
\text { low }\end{array}$ \\
\hline $\begin{array}{l}\text { Harris, Rowe- } \\
\text { Mississ, \& } \\
\text { Somerset } \\
(2014)\end{array}$ & Logan & $\begin{array}{l}\text { Adult refugees } \\
\text { and asylum } \\
\text { seekers }\end{array}$ & $n=12$ & African & $\begin{array}{l}\text { Community garden } \\
\text { program for } \\
\text { refugees and } \\
\text { asylum seekers }\end{array}$ & $\begin{array}{l}\text { Cross-sectional } \\
\text { study using semi- } \\
\text { structured } \\
\text { interviews }\end{array}$ & $\begin{array}{l}\text { 1. Land tenure through } \\
\text { garden plots enables a } \\
\text { sense of citizenship. } \\
2 \text {. Reconnecting with } \\
\text { agriculture enables } \\
\text { refugees to celebrate the } \\
\text { family/community } \\
\text { background and } \\
\text { practice/share skills. } \\
\text { 3. The community garden } \\
\text { plays a positive role in } \\
\text { building relationships and } \\
\text { facilitating integration into } \\
\text { society. }\end{array}$ & High \\
\hline $\begin{array}{l}\text { Liamputtong, } \\
\text { Koh, } \\
\text { Wollershiem, \& } \\
\text { Walker, (2016) }\end{array}$ & Melbourne & $\begin{array}{l}\text { Adult refugee } \\
\text { women }\end{array}$ & $n=29$ & $\begin{array}{l}\text { Burmese } \\
\text { Afghan } \\
\text { Sudanese }\end{array}$ & $\begin{array}{l}\text { Peer mentoring } \\
\text { program for } \\
\text { refugee women } \\
\text { utilizing mobile } \\
\text { phones }\end{array}$ & $\begin{array}{l}\text { Qualitative study } \\
\text { using participant } \\
\text { interviews }\end{array}$ & $\begin{array}{l}\text { 1. Many participants } \\
\text { reported that the program } \\
\text { "made a huge difference } \\
\text { in their lives". } \\
\text { 2. New social networks } \\
\text { were created. } \\
\text { 3. Stronger relationships } \\
\text { developed. } \\
\text { 4. Participants } \\
\text { experienced increased }\end{array}$ & High \\
\hline
\end{tabular}




\begin{tabular}{|c|c|c|c|c|c|c|c|c|}
\hline & & & & & & & $\begin{array}{l}\text { wellbeing and reduced } \\
\text { social isolation. } \\
5 . \text { Participants enjoyed } \\
\text { increased social support. } \\
6 \text {. Peer support was } \\
\text { identified as contributing } \\
\text { to a positive settlement } \\
\text { experience. }\end{array}$ & \\
\hline Naidoo (2009) & Sydney & $\begin{array}{l}\text { Tutors and } \\
\text { teachers of } \\
\text { refugee } \\
\text { students not } \\
\text { refugees } \\
\text { themselves }\end{array}$ & $\begin{array}{l}n=30 \text { tutors } \\
\text { in focus } \\
\text { groups plus } \\
\text { interviews } \\
\text { with tutors } \\
\text { and teachers }\end{array}$ & $\begin{array}{l}\text { African } \\
\text { students } \\
\text { Mentors } \\
\text { nationality } \\
\text { unknown }\end{array}$ & $\begin{array}{l}\text { Home-work } \\
\text { tutoring program } \\
\text { involving university } \\
\text { students as } \\
\text { mentors for school- } \\
\text { aged refugees and } \\
\text { asylum seekers }\end{array}$ & $\begin{array}{l}\text { Ethnographic } \\
\text { investigation }\end{array}$ & $\begin{array}{l}\text { 1. After school homework } \\
\text { clubs enable the } \\
\text { development of cultural } \\
\text { capital amongst refugees } \\
\text { that can then be traded } \\
\text { for economic and social } \\
\text { capital. } \\
\text { 2. Social inclusion can be } \\
\text { achieved by enhancing } \\
\text { economic and academic } \\
\text { participation. }\end{array}$ & Medium \\
\hline $\begin{array}{l}\text { Riggs, Block, } \\
\text { Mhlanga, Rush } \\
\text { \& Burley } \\
\text { (2014) }\end{array}$ & $\begin{array}{l}\text { Regional } \\
\text { Victoria (La } \\
\text { Trobe } \\
\text { Valley) }\end{array}$ & $\begin{array}{l}\text { Learner drivers } \\
\text { from refugee } \\
\text { backgrounds }\end{array}$ & $\begin{array}{l}n=9 \text { mentees } \\
n=2 \text { mentors }\end{array}$ & African & $\begin{array}{l}\text { Refugee driver } \\
\text { education program }\end{array}$ & $\begin{array}{l}\text { Qualitative study } \\
\text { using participant } \\
\text { interviews }\end{array}$ & $\begin{array}{l}\text { 1.Four participants } \\
\text { obtained their drivers' } \\
\text { license as a result of their } \\
\text { involvement in the } \\
\text { program. } \\
\text { 2. Mentor and mentees } \\
\text { identified that the } \\
\text { program helped them to } \\
\text { meet new people. } \\
\text { 3.Communication } \\
\text { challenges were } \\
\text { common. } \\
\text { 4. There were not enough } \\
\text { trained mentors to } \\
\text { volunteer in the program } \\
\text { creating long wait times. }\end{array}$ & Low \\
\hline
\end{tabular}




\section{Discussion}

Currently, there is a very limited body of research exploring community-based programs aimed at building social inclusion amongst refugees and asylum seekers in Australia. Programs have utilized diverse interventions including using mobile phone technology, community gardens, skill development (homework clubs and learner driver programs) and general recreation programs for children. Overall, the studies provided a limited foundation from which to make strong predictions about program effectiveness. Despite the interventions being significantly varied in nature, several themes were identified across the studies that underpin, and contribute to, program effectiveness as outlined below.

\section{English language, communication processes and tools}

It is clear from the papers reviewed that English language and communication skills are a key requirement for building social inclusion, and at the same time, a potential stumbling block in community-based programs. For example, in Riggs, Block, Mhlanga, Rush, and Burley (2014) the driving mentors identified that program participants needed training in communication skills in order to re-schedule their appointments and that communicating in English was a particular challenge for understanding driving instructions.

The women in Liamputtong, Koh, Wollersheim, and Walker's (2016) study identified that the mobile phone peer mentoring program helped participants to practice their English skills more regularly, thereby enhancing their language acquisition. Access to a mobile phone allowed the women to feel more 'informed' and to have better knowledge about things around them. Use of a mobile phone led to better connection with daily activities such as finding essential ingredients for cooking, connecting with healthcare providers more efficiently and staying connected with their children and communities. This study demonstrated the importance of modern communication tools in enabling social connection and relationship building, and conversely, noted how the lack of access to such technology may results in a sense of exclusion and social isolation amongst refugees and asylum seekers. The study reinforced findings by Alam and Imran (2015) about the high usage of mobile phone technology and social media platforms in Australia, and their capacity to alienate those not yet connected.

Naidoo's (2009) ethnographic study documented the experiences of university student mentors working in a homework club for students from a refugee-background. The club focused on English language support and educational improvement and attainment. In this context, language acquisition was seen to be central to social and economic inclusion for upward mobility to be achieved.

\section{Building on cultural knowledge and pre-settlement practices}

The study by Harris, Rowe-Minniss, and Somerset (2014), in which refugees participated in a community food garden, highlighted the importance of recognizing that refugees and asylum seekers arrive with previous life experiences and knowledge. Enabling participants in the community garden program to tap into and share their pre-settlement skills in gardening and food production encouraged a two-way exchange between the newly arrived and their host community. In addition, the program was found to have a significant impact on the sense of citizenship of participants, through the provision of land tenure, providing an insight into how transformational this gesture can be in the lives of refugees, many of whom have previously lived or worked in agrarian societies. Similarly, Liamputtong et al., (2016) identified that the older women in their study tended to take younger women under their wing, enabling unaccompanied or single refugees to experience a sense of parental and family support and vice versa. The study showed that building such social bonds, through having similar cultural or national identities, helped to strengthen relationships and build a sense of safety and community amongst refugees. 


\section{Trained volunteer and mentor involvement in social inclusion programs}

Four of the five studies involved mentors or volunteers in the delivery of the community-based interventions. This involvement, while not specifically evaluated in the individual studies themselves, emerges from the data as a key feature of community-based interventions. The studies all identified the importance of volunteers to program delivery and the need to recruit and train them as part of an effective program. However, the majority of studies did not assess the quality of volunteer input and involvement. The study by Riggs et al. (2014, p90), clearly demonstrated that a shortage of volunteers can hamper the effectiveness and scope of programs, citing a lack of volunteers as a "major impediment".

Two of the studies interviewed program mentors to ascertain their views on the impact of the program. Cultural awareness and peer support training were highly valued by participants in the studies by Liamputtong et al. (2016) and Riggs et al. (2014). If volunteers are required, or indeed critical to the delivery of community-based programs, then it is necessary to consider their recruitment, training and support when designing interventions.

Most of the studies highlighted the two-way nature of building social inclusion, with host community volunteers. Naidoo's (2009) study involving volunteer trainee teachers in the homework club demonstrated that the intervention provided an important opportunity for the trainee teachers to develop knowledge of the students' experiences of resettlement and the academic and family challenges faced by this cohort, thereby enhancing their professional skills. Riggs et al. (2014) also noted that mentor drivers valued the opportunity to meet and get to know new people.

\section{Making new connections through offering a diverse range of programs}

Social inclusion by its very nature is a two-way process of forging new connections, requiring interactions between the host community and newly arrived refugees and asylum seekers (Ager \& Strang, 2008; Fozdar \& Hartley, 2013). All of the studies reviewed, whether facilitated by human service practitioners, volunteers or mentors, or a combination of these, had a focus of building the social connectedness and wellbeing of participants. The interventions, while diverse in nature, are designed to enable new social connections as part of the process of building inclusion. This occurred within cultural groups involved in the intervention, and also with workers, volunteers or mentors from the host community (Harris et al., 2014; Liamputtong et al., 2016).

Building 'social bonds' and 'social bridges', which have been identified as foundations for social inclusion (Ager \& Strang, 2008), were a focus of the interventions. Pro-actively facilitating the participation of refugees and asylum seekers in community programs helped to establish new connections - either within their own community or within host community networks. All the studies seemed to achieve stronger social relationships for their participants, demonstrating that there are many types of programs that can achieve this goal and programs need not be restricted to one particular activity.

Liamputtong et al. (2016) specifically identified that mobile phone use diminished the sense of isolation felt by refugee participants as they built new and stronger relationships within their community. The community garden program (Harris et al., 2014) demonstrated that participants had achieved a strong sense of belonging within their new community and that the growing and sharing of food is a collaborative activity suited to increasing social inclusion.

\section{Limitations and future directions}

A limitation of the present review is that the literature screening process and data extraction were conducted only by the first author. This review also identified a number of limitations with existing literature exploring community-based programs for social inclusion of refugees and 
asylum seekers. A number of studies described participants as being 'African', without delineating specific cultural and ethnic backgrounds of the participants and potentially overlooking cultural differences that may exist between different groups. Similarly, the studies covered a wide range of program types and participant ages, some involved only one gender, and sample numbers were low. These factors limited the ability to compare results across studies effectively. The geographical locations of the studies varied and therefore the transferability of programs into different cities or rural and regional Australia is not known.

Programs for refugee children and young people were sparse in the literature. Given that $51 \%$ of currently displaced people have been identified by the UNHCR as children, there could be more focus on programs that might support their social inclusion and participation in Australia (RCOA, 2016a). Although several articles about refugee youth and sporting clubs were identified, they did not meet the criteria for inclusion in the review.

\section{Conclusion}

Although there appears to be a growing trend to showcase individual success stories of refugees and their achievements in social, economic and cultural life, this is not matched by high quality empirical research in Australia (RCOA, 2010). This systematic review has identified a significant shortage of well-researched and evaluated community-based programs aimed at increasing the social inclusion of refugees and asylum seekers in Australia.

Where there has been an evaluation of the effectiveness of community-based programs, most studies have involved limited numbers and diversity of participants and therefore the generalizability of findings is limited. Despite the lack of rigorous evaluation, it is evident that community-based programs do have a positive effect on participants by increasing their social inclusion and connectedness.

Some elements that underlie, and support the effectiveness of programs, include embedding English language acquisition or communication skills and tools into programs; tapping into and building on the pre-settlement skills and knowledge of refugees and asylum seekers; recruiting, training and supporting the volunteers and mentors involved in program delivery; and offering a diverse range of community-based programs in order to facilitate interactions with the host community population.

If government agencies, community groups, human services practitioners, and volunteers are to be effective in their efforts then focusing more attention on the design, delivery and rigorous evaluation of community programs and interventions is critical to establishing an evidence base for building social inclusion for refugees and asylum-seekers. Considering that refugee and resettlement issues significantly dominate the Australian and international media, there is a clear need for more research in this area. 


\section{References}

Ager, A. \& Strang, A. (2008). 'Understanding Integration: a conceptual framework', Journal of Refugee Studies, 2 (2): 166-191.

Alam, K. \& Imran, S. (2015). 'The digital divide and social inclusion among refugee migrants: A case in regional Australia', Information Technology \& People, 28 (2): 344-365.

Australian Bureau of Statistics (ABS). (2017). Census reveals a fast-changing, culturally diverse nation. Retrieved from:

http://www.abs.gov.au/ausstats/abs@.nsf/lookup/Media\%20Release3

Australian Department of Social Security (ADSS). (2016). Annual Report 2015-16. Retrieved from:

https://www.dss.gov.au/sites/default/files/documents/10_2016/dss_annual_report_2 015-16.pdf

Australian Government. (n.d.). Social inclusion principles for Australia. Retrieved from: http://meetingpoint.org.au/assets/mp_s12_sipfa.pdf

Beirens, H., Hughes, N., Hek, R., \& Spicer, N. (2007). 'Preventing social exclusion of refugee and asylum seeking children: building new networks', Social Policy and Society, 6 (2): 219-229.

Benson, S. (2017). 'Integration core in new multicultural policy', The Australian, 20 March 2017. Retrieved from: http://www.theaustralian.com.au/national-affairs/integrationcore-to-australian-identity-in-new-multicultural-policy/newsstory/45a28c82a4a1f4d8ede71c8661c582f3

Brown Hamilton, T. (2016). 'Losing identity during the refugee crisis', The Atlantic, 16 May 2016. Retrieved from:

https://www.theatlantic.com/education/archive/2016/05/balancing-integration-andassimilation-during-the-refugee-crisis/482757/

Correa-Velez, I., Gifford, S. \& Barnett, A. (2010). 'Longing to belong: social inclusion and wellbeing amongst youth with refugee backgrounds in the first three years in Melbourne, Australia', Journal or Social Science \& Medicine. 71: 1399-1408.

Cowell, A. (2015). 'Migrants provoke an identity crisis in Europe', The New York Times. 25 June 2015. Retrieved from:

https://www.nytimes.com/2015/06/26/world/europe/migrants-provoke-an-identitycrisis-in-europe.html? $r=0$

Davidson, H. (2016). 'Offshore detention: Australia's recent immigration history a 'human rights catastrophe", The Guardian, 13 November 2016. Retrieved from: https://www.theguardian.com/australia-news/2016/nov/13/offshore-detention-nauruimmigration-history-human-rights

Fozdar, F. \& Hartley, L. (2013). 'Refugee resettlement in Australia: What we know and what we need to know', Refugee Survey Quarterly, 32 (3): 23-51.

Fozdar, F. \& Hartley, L. (2014). 'Civic and ethno belonging amongst recent refugees to Australia', Journal of Refugee Studies, 27 (1): 126-144.

Grant, M. J., \& Booth, A. (2009). 'A typology of reviews: An analysis of 14 review types and associated methodologies', Health Information and Libraries Journal, 26: 91-108.

Hallahan, L. \& Irizarry, C. (2008). 'Fun Days Out: Normalising social experiences for refugee children', Journal of Family Studies, 14 (1): 124-130.

Hannes, K. (2011). 'Chapter 4: Critical appraisal of qualitative research', in: Noyes J, Booth A, Hannes K, Harden A, Harris J, Lewin S, \& Lockwood C (editors), Supplementary Guidance for Inclusion of Qualitative Research in Cochrane Systematic Reviews of Interventions. Version 1. Cochrane Collaboration Qualitative Methods Group, 2011. Retrieved from: http://cqrmg.cochrane.org/supplemental-handbook-guidance

Harris, N., Rowe-Minniss, F. \& Somerset, S. (2014). 'Refugees connecting with a new country through community food gardening', International Journal of Environmental Research and Public Health, 11: 9202-9216. 
Liamputtong, P., Koh, L., Wollersheim, D. \& Walker, R. (2016). 'Peer support groups, mobile phones and refugee women in Melbourne', Health Promotion International, 31: 715724.

Logan City Council (2016). Working together to help Syrian refugees settle in Logan. Retrieved from: http://www.logan.qld.gov.au/community-support/city-ofchoice/news-and-achievements/city-of-choice-news/working-together-to-helpsyrian-refugees-settle-in-logan

Markus, A. (2016). Mapping social cohesion. The Scanlon Foundation surveys 2016. Monash University. Melbourne. Retrieved from: http://scanlonfoundation.org.au/wpcontent/uploads/2016/11/2016-Mapping-Social-Cohesion-Report-FINAL-withcovers.pdf

Moher, D., Liberati, A., Tetzlaff, J., Altman, D. G. \& The PRISMA Group (2009). 'Preferred reporting items for systematic reviews and meta-analyses: The PRISMA statement', PLOS Medicine, 6 (7): e1000097.

Naidoo, L. (2009). 'Developing social inclusion through after-school homework tutoring: a study of African refugee students in Greater Western Sydney', British Journal of Sociology of Education, 30 (3): 261-273.

Organisation for Economic Co-operation and development (OECD). (2009). International Migration Outlook 2009. Retrieved from: http://www.oecd.org/els/mig/internationalmigrationoutlook2009.htm\#STATISTICS

Organisation for Economic Co-operation and Development (OECD). (2011). Conference proceedings. Retrieved from:

http://www.oecd.org/dev/pgd/internationalconferenceonsocialcohesionanddevelopm ent.htm

Ott, E. \& Montgomery, P. (2015). 'Interventions to improve the economic self-sufficiency and wellbeing of resettled refugees: a systematic review', Campbell Systematic Reviews, 2015:4

Paterson, T. (2015). 'Refugee crisis: Germany's welcome culture fades as thousands continue to arrive', The Independent, 7 October 2015. Retrieved from: http://www.independent.co.uk/news/world/europe/refugee-crisis-germanyswelcome-culture-fades-as-thousands-continue-to-arrive-a6685361.html

Postelnicescu, C. (2016). 'Europe's new identity: The refugee crisis and the rise of nationalism', European Journal of Psychology, 12 (2): 203-209.

Refugee Council of Australia (RCOA). (2010). Economic, civic and social contributions of refugees and humanitarian entrants. Retrieved from: http://www.refugeecouncil.org.au/docs/resources/Contributions_of_refugees.pdf

Refugee Council of Australia (RCOA). (2016a). UNHCR Global Trends - How Australia Compares with the World. Retrieved from:

http://www.refugeecouncil.org.au/getfacts/statistics/unchr2015/

Refugee Council of Australia (RCOA) (2016b). Who are asylum seekers? Retrieved from: https://www.refugeecouncil.org.au/getfacts/international/definitions/who-are-asylumseekers/

Riggs, E., Block, K., Mhlanga, T., Rush, C., \& Burley, M. (2014). 'On the road to inclusion: Evaluation of a refugee driver education program in regional Victoria, Australia', Journal of Social Inclusion, 5 (1): 85 - 94.

Robjant, K., Hassan, R. \& Katona, C. (2009). 'Mental Health Implications of detaining asylum seekers: systematic review', British Journal of Psychiatry, 194: 306-312.

Szabo, S. (2015). 'Europe's' identity crisis', in The Washington Post, 12 November 2015. Retrieved from:

https://www.washingtonpost.com/news/in-theory/wp/2015/11/12/the-europeanidentity-crisis/?utm_term=.30af473fb6bb

Taylor, J. (2004). 'Refugees and social exclusion: what the literature says', Migration Action, 26 (2): 16-31. 
Tyrer, R. A. \& Fazel, M. (2014). 'School and community-based interventions for refugee and asylum seeking children: A systematic Review', PLoS ONE, 9 (2): e89359.

United Nations High Commissioner for Refugees (UNHCR). (2017). Convention and Protocol relating to the status of refugees. Retrieved from: http://www.unhcr.org/enau/3b66c2aa10

United Nations High Commissioner for Refugees (UNHCR). (2016). Figures at a glance. Retrieved from: http://www.unhcr.org/en-au/figures-at-a-glance.html

United Nations Department of Economic and Social Affairs (UNDESA). (2012). Perspectives on social cohesion - the glue that holds society together. Retrieved from: http://www.un.org/en/development/desa/news/policy/perspectives-on-socialcohesion.html 


\section{Biographical Notes}

Di Mahoney is a human services practitioner with more than twenty years' experience working in community \& environmental organisations, local government and higher education. Her research and practice interests include the effective participation, engagement and inclusion of young people, refugees, women and other equity groups in community-based or government-funded programs that aim to enhance their social, education, employment and life opportunities.

Samantha Siyambalapitiya is a speech pathologist and Senior Lecturer in the School of Allied Health Sciences at Griffith University. Her research explores communication disability in multilingual individuals and the provision of healthcare to people from culturally and linguistically diverse backgrounds. 